briefly. But in general he tells the complex multinational tale clearly and well, although at times he is repetitious and didactic. From his research in Switzerland and the United States he has unearthed much relevant new material on the early women pioneers, including some letters that they wrote back to home and to each other. And it is also clear that these pioneers did not remain totally obscure: in fact, their presence was often such a cause célèbre as to

\section{Worldly wise}

Peter J. Smith

Encyclopedla of Earth System Science. Volumes 1-4. Editor-in-chief William A. Nierenberg. Academic: 1992. \$950, $£ 573$.

WHAT is this new 'Earth system science' and, in particular, how does it differ from plain old Earth science? The answer to the second part of this question, which also happens to be the answer to the first, is that there is no difference at all in substance but only in emphasis, and that the alleged novelty of the emphasis is more imaginary than real.

"In the past few decades", claims Robert M. White, president of the US National Academy of Engineering, in the foreword to this huge encyclopaedia, "humanity has come to understand that all parts of the earth system, the oceans, the atmosphere, the solid earth, the biosphere, and the near space surrounding it, make up a continuously interacting whole." I doubt it. The vast mass of humanity has never given such matters even a passing thought; and if by 'humanity' White simply means those involved, however peripherally, in and with the Earth and environmental sciences, they were aware of the interconnectedness of Earth processes long, long ago. The literature is replete with examples of solid-Earth-oceanic-atmosphericbiospheric interactions, ranging from the outgassing from the solid Earth of an atmosphere and oceans subsequently modified by chemical, biological and human activity to the way in which processes deep in the Earth influence inhabitants of seismic and volcanic zones.

The problem, as it always has been, is not lack of awareness of terrestrial interactions but the ability to understand them in scientific detail. And therein perhaps lies a tale, for greater scientific understanding needs money, and lots of it. There may be little new in Earth system science apart from the name, but cynics would argue, applying the Windscale-Sellafield principle, that re486 generate both derisive and supportive cartoons. Bonner's book is the best one-volume survey of this complex subject, and deserves wide use in the increasing number of courses on women's history, women and science, and the history of medicine.

Margaret W. Rossiter is in the Department of Science and Technology Studies, Cornell University, 632 Clark Hall, Ithaca, New York 14853, USA.

naming is precisely the point. Now that politicians have become interested in Earth-environmental matters, which by their very nature involve complex natural interactions, there may be considerable financial advantage to be had in pretending that poised to solve the problems is not some fuddy-duddy-sounding science with 200-year-old roots but a glossy new concept dressed in high-tech jargon.

In this context, the Encyclopedia of Earth System Science can be seen as part of the talking-up, or softening-up, process. It may be simply an encyclopaedia of the Earth sciences under another name and it is certainly not, as White appears mistakenly to believe, any more interdisciplinary than would be any other encyclopaedia of the Earth sciences published in 1992. It neither records a quantum leap in interdisciplinary understanding nor, obviously, is able to take such understanding beyond what the current state of knowledge will allow. What is true, however, is that it is the first multidisciplinary encyclopaedia of the Earth sciences to appear; and there may be some merit in that if it encourages interdisciplinary studies in the future.

What we have, then, are four tomes comprising more than 2,600 pages of text and containing 230 articles with an average length of about 12 (large) pages each, although there is considerable variation about the mean. Each article includes, in order, a list of the sections therein, a general abstract-style introduction, a more specific introduction to the subject, a text divided into sections, a modest bibliography emphasizing books and reviews, and a short glossary. The final volume also contains a list of contributors, a 13-page 'relational index' comprising general headings under each of which is a list of relevant articles (very useful), and a detailed 171-page subject index (even more useful).

The subjects covered range from acid rain, acoustical oceanography, Antarctica and atmospheric tides, through magma chamber dynamics, marine pollution, the Messinian salinity crisis and microplates, to tsunamis, volcanic tremor, wood moisture and the environment, and zonal and meridianal winds in the Earth's atmosphere. As this short list covers just 5.2 per cent of the articles, it can do no more than give a flavour of the contents, although I hope it is sufficient to illustrate the huge range of topics included.

What I have read and skimmed which is about as much as one can reasonably do in an average working week - has been generally well written and, indeed, so uniformly well written that I cannot but conclude that, unusually in these days, the volumes have actually been edited and not merely compiled. I could have wished that the articles had been equally uniformly comprehensible, although perhaps that was too much to hope for given natural variations in subject complexity. Thus whereas many of the articles will be easily understood by the "policymakers and administrators" that Nierenberg hopes to include among his audience, many will not, and some (for example, that on the origin of the geomagnetic field) will be accessible only to those with PhDs in, and several years' experience of, advanced mathematics (which does not include me).

One cannot but be impressed by the scale and quality of the enterprise, although the former must be put in perspective. In spite of its great length, this new encyclopaedia is actually less comprehensive within individual fields (such as the solid Earth) than are some recent, more specific volumes (such as The Encyclopedia of Solid Earth Geophysics, Van Nostrand Reinhold, 1989). More importantly, however, what influence is it likely to have? No individual will be able to afford it; it will be beyond the resources of any UK public library, given the recently publicized crisis in that system; most university libraries are in an equally parlous position; and it is not the sort of thing that could usefully be borrowed for a couple of weeks from the National Lending Library. So who, in the United Kingdom at least, will ever see it?

Peter J. Smith is in the Department of Earth Sciences, The Open University, Milton Keynes MK7 6AA, UK.

\section{Addendum}

Apoptosis: The Molecular Basis of Cell Death (Cold Spring Harbor Laboratory Press), reviewed in the issue of 5 March, is edited by Frederick 0 . Cope, in addition to David Tomei.

\section{Spring Books}

Appearing in next week's issue is Nature's Spring Books supplement. Featured, among others, are Huw Price on the enigma of Paul Davies; Richard Davenport-Hines on miasmas and disease; Colin Renfrew on the Atlantis legend; Walter Gratzer on Otto Warburg; David L. Hull on sexual selection; David M. Ritson on Edward Teller; Ed Regis on Caltech; and lan Stewart on Buckminster Fuller's "scenario for the future of humanity". NATURE · VOL $356 \cdot 9$ APRIL 1992 